\title{
EVALUATION OF CELLULAR IMMUNE FUNCTION AND GASTRIC TUMOUR FOR BIOMARKERS AFTER EARLY ENTERAL NUTRITION
}

\author{
XIANMIN BU ${ }^{1 \#}$, FANGFANG XU $^{1 \#}$, JIE MA $^{2}$, LI WEI $^{1 *}$ \\ ${ }^{1}$ Pathology Department, Jining No.1 People's Hospital, Jining, 272111, Shandong, China \\ ${ }^{2}$ Oncology Department, Jining No.1 People's Hospital, Jining, 272111, Shandong, China \\ *corresponding author:lwrmyy@yeah.net \\ \#Authors have equally contributed to the current paper and shared first authorship
}

Manuscript received: January 2018

\begin{abstract}
Gastric cancer has high morbidity and disability rates that influence the cellular immune function and the life quality of patients. Surgery is the first option for the treatment of gastric cancer and in some cases, it is combined with chemotherapy and radiotherapy. This study aimed to evaluate the role of early enteral nutrition after gastric cancer surgery on postoperative cellular immune function and cancer biomarkers. One hundred patients with gastric carcinoma were included in the study. Patients were divided into the experimental group A and control group B, including 50 patients per group. Group A received early enteral nutrition treatment and group B received early parenteral nutrition treatment. The percentage of CD3+ T cells, CD4 + T cells, CD8+ T cells, NK cells, the CD4+/CD8 + ratio and the levels of CEA, CA125, CA19-9 were measured one day before the surgery, one day after the surgery and 14 days after the surgery in both groups. The percentage of CD3+ and $\mathrm{CD} 4+\mathrm{T}$ cells, the ratio of $\mathrm{CD} 4+/ \mathrm{CD} 8+$ and the percentage of $\mathrm{NK}$ cells was decreased in group A and group B one day after surgery compared with the levels before surgery. The decrease was significantly higher in group A compared with group B at 14 days after surgery. CEA, CA125, CA19-9 levels in both groups were decreased one day after surgery compared to the levels before surgery and this decrease was more significant in group A compared to group B, 14 days after surgery. Early enteral nutrition after gastric cancer surgery could effectively improve the patient's cellular immunity level and reduce the tumour markers in gastric cancer patients.
\end{abstract}

\section{Rezumat}

Cancerul gastric prezintă o mortalitate și o rată de invaliditate crescută care influențează imunitatea şi calitatea vieții pacienților. La ora actuală principala opțiune terapeutică este intervenția chirurgicală asociată cu chimioterapie și radioterapie. Prezentul studiu își propune să evalueze rolul nutriției enterale după gastrectomie, în modularea imunității celulare și a markerilor tumorali. În studiu au fost incluși o sută de pacienți cu cancer gastric. Pacienții au fost împărțiți întrun grup experimental, grupul A și un grup de control, grupul B. Grupul A a primit nutriție enterală imediat după operație, iar grupul B a primit nutriție parenterală imediat după operație. Procentul celulelor T de tip CD3+, CD4+, CD8+, NK, raportul CD4+/CD8+ și nivelul de CEA, CA125, CA19-9 au fost determinați la o zi înainte de operație, la o zi după operație și la 14 zile după operație. Procentul celulelor T de tip CD3+ şi CD4+, a celulelor NK şi raportul CD4+/CD8+ au scăzut în ambele grupuri la o zi după operație comparativ cu valorile dinainte de operație, scăderea fiind semnificativ crescută în grupul A comparativ cu grupul B la 14 zile după operație. În ceea ce privește valorile CEA, CA125 și CA19-9 în ambele grupuri aceștia au scăzut la o zi după operație, scăderea fiind mult mai semnificativă în grupul A la 14 zile după operație comparativ cu grupul B. Nutriţia enterală imediat după operația de cancer gastric poate îmbunătăți eficient imunitatea celulară a acestor pacienți și reduce nivelul markerilor tumorali.

Keywords: postoperative gastric cancer patients, early enteral nutrition, cellular immunity, CD4+/CD8+ ratio, tumour biomarkers, CEA, CA125, CA19-9

\section{Introduction}

Gastric cancer has a significant burden on public heath, its incidence increases over the years due to dietary and lifestyle factors $[6,20]$. Several processed food contain carcinogens that may be implicated in the onset and development of gastric carcinoma $[1$, 18, 19].

Gastric cancer has a high morbidity rate and a high disability rate, that influence the cellular immune function and the life quality of the patients $[8,12$,
14]. The treatment of gastric cancer depends on the stage of the cancer and other prognosis markers. These markers including e-cadherin, epidermal growth factor (EGF) and its receptors, tumour growth factor beta (TGF-beta) and its receptors can indicate the severity and the prognosis of the disease [17]. The main therapeutic approach is surgery, total or subtotal gastrectomy, and in some cases it is combined with chemotherapy or chemoradiation. Gastric cancer surgery can cause 
FARMACIA, 2018, Vol. 66, 4

further damage to the body and influence the quality of life of these patients, thus finding new methods for better recovery after gastrectomy has attracted researchers' attention. Jiang et al studied the impact of operating room nursing and home nursing on postoperative recovery and prognosis of cancer patients and found that the extubation time and post-operative recovery time were decreased in the patients to whom nursing methods were applied compared to the control group. Those patients had improved physical condition, indicating that home nursing could have a positive effect on postoperative recovery and prognosis of gastric cancer patients after gastrectomy [10]. Roy et al studied the effect of physical and psychological care on the survival rate of patients after gastrectomy and showed that these methods can improve their nutrition and physical conditions that lead to an increased survival rate [15]. This study aimed to investigate the role of early enteral nutrition on postoperative rehabilitation of patients with gastric cancer after gastrectomy.

\section{Materials and Methods}

\section{Patients}

One hundred patients with gastric carcinoma admitted to No.1 People's Hospital, Jining, Shandong, China, during January 2016 and March 2017 were included in the study. The exclusion criteria were: patients who could not receive gastric cancer treatment; patients who received hormone therapy; patients with poor compliance; patients with severe immune disorders and patients with hypercholesterolemia. The included patients were divided into group A (experimental group) and group B (control group), 50 patients per group. There were 21 male patients and 29 female patients in group A, with an age range of 46-61 years old (average: $54.9 \pm 1.3$ years old) and 26 male patients and 24 female patients in group $B$, with an age range of 44-68 years old (average: $55.1 \pm 0.8$ years old). There was no significant difference between the two groups regarding sex or age $(p>0.05)$. The study was approved by the Medical Ethics Committee of the hospital, and all patients participating in the study signed an informed consent.

Nursing method

The nursing treatment was provided after radical gastric cancer surgery in both groups.

Group A: The nutrition tube was placed in the stomach tube before surgery and fixed by line 4 . During surgery, the nutrition tube was inserted into and fixed at the distal end of the gastrointestinal anastomosis with the gastric tube. One day after surgery, $250 \mathrm{~mL}$ of isotonic saline solution (Nanjing Bianzhen Biotechnology Co., Ltd.) was injected to the patients and their blood flow dynamic condition was monitored. If the blood flow dynamic condition was stable and there was no abdominal pain and abdominal distension, the patients were injected with enteral nutrition solution (Nutricia Pharmaceutical (Wuxi) Co., Ltd.). Nutritional fluid pump was used to control the injection rate to 40 $\mathrm{mL} / \mathrm{h}$, and the incidence of adverse reactions was observed. If the patients had adverse reactions, the injection rate would be adjusted to $90-120 \mathrm{~mL} / \mathrm{h}$ the next day. Nutrition solution was injected to the patients in the second and third day after surgery by $550 \mathrm{~mL}$ and $1100 \mathrm{~mL}$ respectively, followed by $2000 \mathrm{~mL} /$ day in the following days. When the patients were able to eat, the total amount of nutrition solution injection was reduced while ensuring that their daily intake of calories was not less than $25 \mathrm{~kJ} / \mathrm{kg}$. When the patients were lack of fluid or energy, intravenous supplement was required.

Group B: before surgery, the nutrition tube was placed in the jugular vein of the patients and nutritional support was initiated 2 days after surgery.

The nutrient solution (Nutricia Pharmaceutical (Wuxi) Co., Ltd.) consisted of amino acids, fat milk, glucose, water-soluble vitamins, fat-soluble vitamins, trace elements and insulin, which were injected at $2.5 \mathrm{~mL}$ each day, for 7 days.

Blood test biomarkers

Immune cell function and tumour markers were tested 1 day before surgery, 1 day after surgery and 14 days after surgery. Cellular immunity was evaluated by the percentage of CD3+ T cells, CD4+ $\mathrm{T}$ cells, CD8+ $\mathrm{T}$ cells and the ratio of $\mathrm{CD} 4+/ \mathrm{CD} 8+$ $\mathrm{T}$ cells. Tumour markers determined were carcinoembryonic antigen (CEA), carbohydrate antigen 125 (CA125) and cancer antigen 19-9 (CA19-9).

Four $\mathrm{mL}$ of venous blood collected on EDTA anticoagulant was used to determine the percentage of CD3 + T cells, CD4+ T cells, CD8+ T cells, NK cells and the ratio $\mathrm{CD} 4+/ \mathrm{CD} 8+\mathrm{T}$ cells.

The main reagents used were CD4-PC5 monoclonal antibody, CD25-FITC monoclonal antibody, CD4FITC/CD8-PE/CD3-PC triple labelling monoclonal antibody and CD16+CD56-PE/CD19-PC5/CD3-FITC fluorescence labelling monoclonal antibody (Beckman Coulter, Inc., USA). The detection was performed according to manufacturer instructions.

Five $\mathrm{mL}$ of blood was collected from the patient after a fasting period. The separated serum was used for CEA, CA19-9 and CA125 detection using a Roche Cobase 601 assay system (Roche Diagnostics $\mathrm{GmbH}$, Germany) and CEA, CA19-9 and CA125 assay kits (Roche Diagnostics $\mathrm{GmbH}$, Germany). 


\section{Statistical analysis}

The SPSS18.0 statistical software package was used for the analysis of the data. Data were expressed as mean \pm standard deviation. Student $t$ test was performed to analyse the differences between the groups, $\mathrm{p}<0.05$ indicates that the differences were statistically significant.

\section{Results and Discussion}

Immune cell modulation

One day after surgery, the percentage of CD3 $+\mathrm{T}$ cells, CD4+ T cells, CD4+/CD8+ ratio and $\mathrm{NK}$ cells in both groups decreased compared with the levels before surgery, while the percentage of CD8
$+\mathrm{T}$ cells increased. Fourteen days after surgery, the percentage of CD3 + T cells, CD4 + T cells, CD8 + $\mathrm{T}$ cells percentage, $\mathrm{CD} 4+/ \mathrm{CD} 8+$ ratio and NK cells in group A increased significantly compared to the levels obtained one day before the surgery and one day after the surgery $(p<0.05)$. Fourteen days after surgery, all the markers determined in group B increased compared with that 1 day after surgery, but the difference was not significant $(\mathrm{p}>0.05)$. Fourteen days after surgery, the cellular immunity markers in group A was higher than that in group $\mathrm{B}$, suggesting that early enteral nutrition could improve cellular immune function $(\mathrm{p}<0.05)$ compared with early parenteral nutrition (Figure 1).
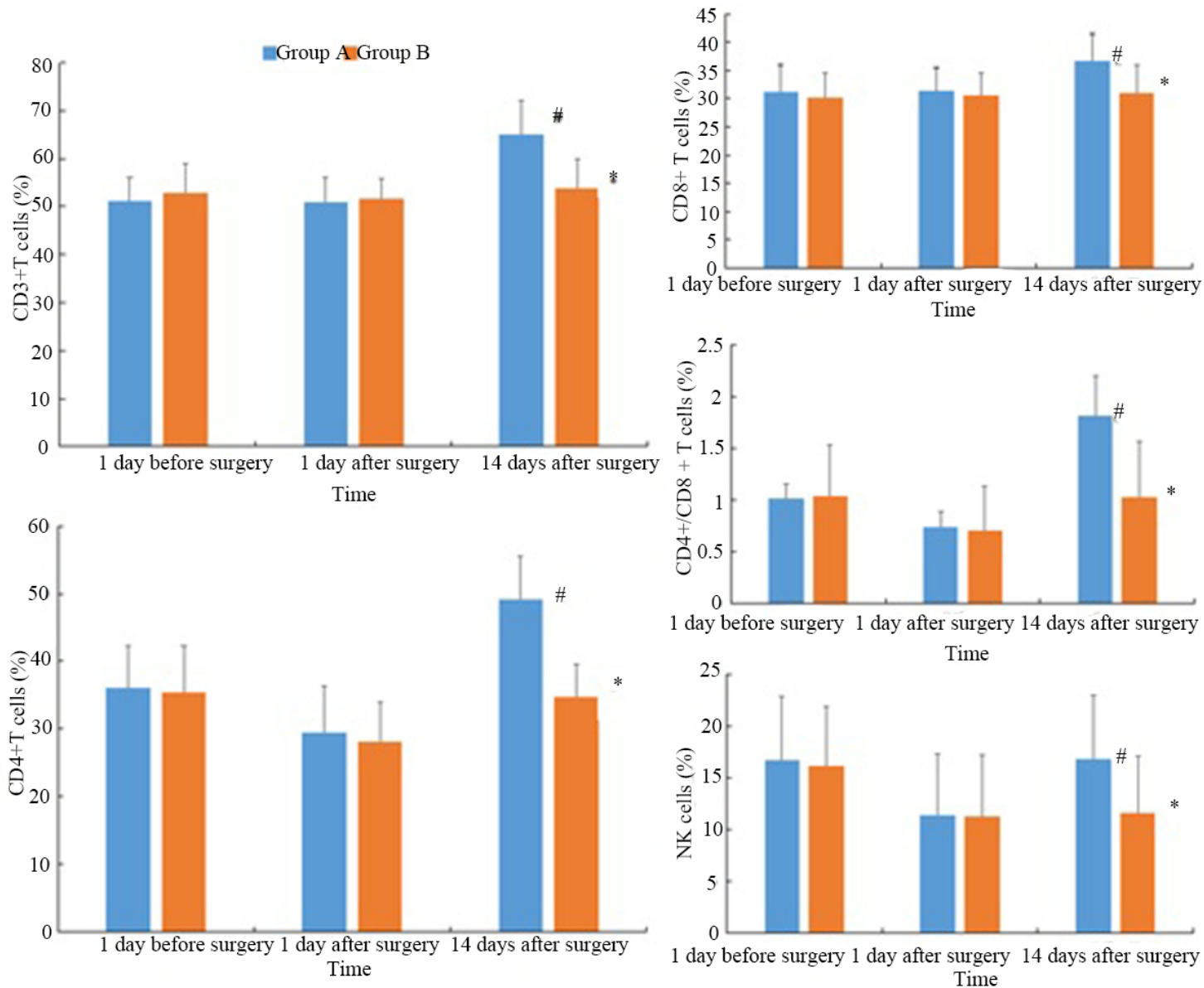

Figure 1.

CD3 + T cells, CD4+ T cells, CD8+ T cells, NK cells percentages and CD4+/CD8+ T cells ratio 1 day before the surgery, 1 day after the surgery and 14 days after the surgery

Note: \# indicates $\mathrm{p}<0.05$ at the 14 th day after surgery compared to group A one day before surgery and one day after surgery; * indicates $p$ $<0.05$ compared to group $\mathrm{A}$ at the same time point

\section{Cancer biomarkers modulation}

As shown in Figure 2, the levels of CEA, CA125 and CA19-9 decreased in both groups one day after surgery compared to the levels before the surgery, but the decrease was not statistically significant $(\mathrm{p}$ $>0.05) .14$ days after surgery, the levels of CEA, CA125 and CA19-9 in both groups had a significant decrease $(p>0.05)$. The levels of CEA,
CA125 and CA19-9 in group A decreased significantly compared with those in group B 14 days after the surgery $(p<0.05)$. These findings suggest that early enteral nutrition nursing could effectively reduce tumour markers and had a positive effect on the evolution and prognosis of gastric cancer patients. 

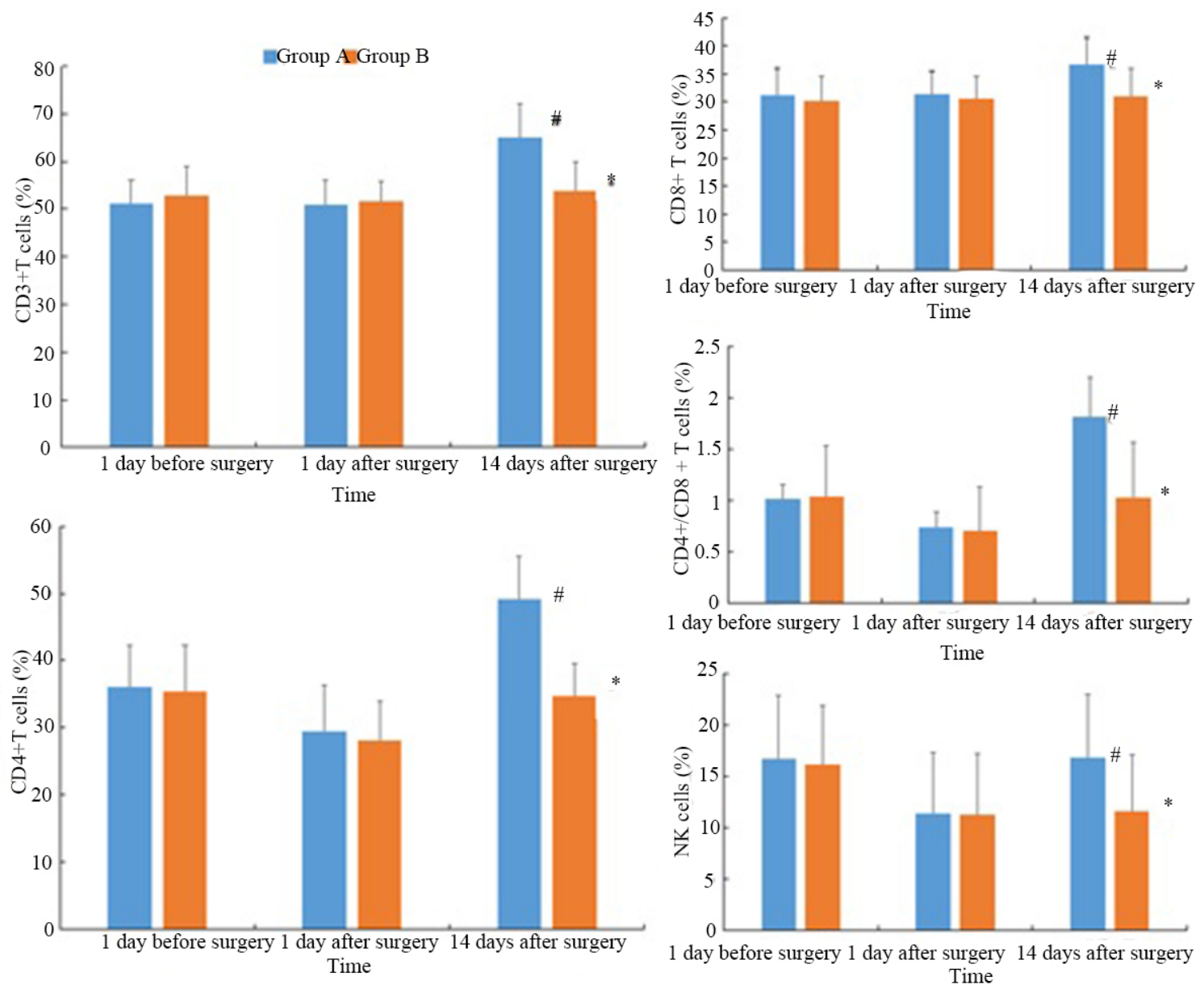

Figure 2.

CD3 + T cells, CD4+ T cells, CD8+ T cells, NK cells percentages and CD4+/CD8+ T cells ratio 1 day before the surgery, 1 day after the surgery and 14 days after the surgery

Note: \# indicates $\mathrm{p}<0.05$ at the 14 th day after surgery compared to group A one day before surgery and one day after surgery; $*$ indicates $\mathrm{p}$ $<0.05$ compared to group A at the same time point

The incidence of gastrointestinal malignancies increases over the last years and the immune system plays an important role [21]. The declined function of the immune system can lead to the development of tumours and which in turn dampen further the immune function [21]. Peripheral blood $\mathrm{CD} 3+\mathrm{T}$ cells and CD4 $+\mathrm{T}$ cells are measured to evaluate the cellular immune function and the number of $\mathrm{CD} 3+\mathrm{T}$ cells can reflect the total amount of $\mathrm{T}$ lymphocytes. Low levels of CD3 $+\mathrm{T}$ cells indicates that the total amount of $\mathrm{T}$ lymphocytes decreases while the assessment of CD4 + T cells represents the levels of T-helper cells that regulate immune function $[11,13]$. Therefore, higher levels of the two cells populations correlate with higher cellular immunity of the human body. $\mathrm{CD} 8+\mathrm{T}$ cells are antitumor killer $\mathrm{T}$ lymphocyte that can effectively inhibit the synthesis and secretion of human antibodies and $\mathrm{T}$ lymphocyte proliferation [9]. Au-Yeung BB et al showed that an increased level of $\mathrm{CD} 8+\mathrm{T}$ associated with a decrease of CD $4+/ \mathrm{CD} 8+\mathrm{T}$ cells ratio cells are correlated with a decline of human immunity [3].

Gastric cancer surgery is the main therapeutic approach against gastric cancer so far. However, the resection surgery can affect the patients' nutritional status, lead to dampening of the immune system, and increase the complications risks and mortality rate $[2,5]$. Therefore, nutritional support is often required after surgery which can improve the nutritional status of patients, the function of the immune system and prognosis. Nutritional support can be either enteral or parenteral. As subclavian vein treatment is required in parenteral nutrition support, infections can easily occur. Besides, longterm parenteral nutrition can stimulate the intestine and lead to declined digestive function. Enteral nutrition support can promote patients to restore bowel function and the insertion of the nutrition tube into the gastrointestinal anastomosis can reduce the possibility of complications and postoperative mortality in patients. 
FARMACIA, 2018, Vol. 66, 4

Tumour markers are proteins, hormones, and antigens secreted by tumour cells [7] which can reflect the level of tumorigenesis in the human body and are closely related to human immunity [4, 7]. Hence, sensitive and specific biological monitoring of gastric cancer markers is crucial for the diagnosis and treatment of early gastric cancer [4]. CEA levels were significantly changed after chemotherapy for gastric cancer. Decrease of CEA after surgery indicates that the treatment was effective. Ca19-9 and CA125 levels can also be potent tumour markers before and after gastric cancer treatment. Changes of CA19-9 and CA125 levels can be used for evaluating the prognosis of the disease. Shao et al analysed the relationship between tumour markers and clinico-pathological parameters and found that preoperative marker levels were very high and when the two markers were combined, the patients with elevated markers showed the worst survival rates [16]. In the present study we showed that the levels of CEA, CA19-9 and CA125 decreased in both groups, but for the group treated with enteral nutrition, the clearance was higher compared to the group treated with parenteral nutrition. It could be noted from the changes of the levels that early enteral nutrition could significantly reduce the levels of tumour markers after gastric cancer surgery and suggested a good long-term prognosis.

\section{Conclusions}

Early enteral nutrition after gastrectomy has positive effects on cellular immune function of gastric cancer patients compared to parenteral nutrition. The effects indicated that early enteral nutrition could reduce the level of tumour markers and increase the survival of gastric cancer patients, being a good option for post-surgery rehabilitation programs

\section{References}

1. Al-Malahmeh AJ, Al-ajlouni AM, Wesseling S, Vervoort J, Rietjens I, Determination and risk assessment of naturally occurring genotoxicand carcinogenic alkenylbenzenes in basil-containing sauce of pesto. Toxicology Reports, 2017; 4: 1-8.

2. Aoyama T, Fujikawa H, Cho H, Ogata T, Shirai J, Hayashi T, Rino Y, Masuda M, Oba MS, Morita S, Yoshikawa T, A methylene blue-assisted technique for harvesting lymph nodes after radical surgery for gastric cancer: a prospective, randomized, controlled study. Am J Surg Pathol., 2015; 39(2): 266-273.

3. Au-Yeung BB, Smith GA, Mueller JL, Heyn C, Jaszczak RG, Weiss A, Zikherman J, IL-2 modulates the TCR signaling threshold for CD8 but Not CD4 T cell proliferation on a single-cell level. J Immunol., 2017; 198(6): 2445-2456.
4. Chen Z, Zheng W, Huang P, Tu DT, Zhou SY, Huang MD, Chen XY, Lanthanide-doped luminescent nano-bioprobes for the detection of tumor markers. Nanoscale, 2015; 7(10): 4274-42790.

5. Ciuhu AN, Rahnea-Niță RA, Popescu M, Badiu CD, Pantea Stoian AM, Lupuliasa D, Gherghiceanu F, Diaconu CC, Rahnea-Niță G, Evidence of strong opioid therapy for palliation of breathlessness in cancer patients. Farmacia, 2017; 65(2): 173-178.

6. Cioates Negut C, Stefan-van Staden RI, Ungureanu EM, Udeanu DI, Stochastic sensors designed for assessment of biomarkers specific to obesity. $J$ Pharm Biomed Anal., 2016; 128: 280-285.

7. Duffy MJ, Harbeck N, Nap M, Molina R, Nicolini A, Senkus E, Cardoso F, Clinical use of biomarkers in breast cancer: Updated guidelines from the European Group on Tumor Markers (EGTM). Eur J Cancer, 2017; 75(1): 284-298.

8. Giron JS, Ospina OE, Massey SE, Elevated levels of adaption in Helicobacter pylori genomes from Japan; a link to higher incidences of gastric cancer? Evol Med Public Health, 2015; 2015(1): 88-105.

9. Hansen SG, Wu HL, Burwitz BJ, Hughes CM, Hammond KB, Ventura AB, Reed JS, Gilbride RM, Ainslie E, Morrow DW, Ford JC, Selseth AN, Pathak R, Malouli D, Legasse AW, Axthelm MK, Nelson JA, Gillespie GM, Walters LC, Brackenridge S, Sharpe HR, López CA, Früh K, Korber BT, McMichael AJ, Gnanakaran S, Sacha $\mathrm{JB}$, Picker LJ, Broadly targeted CD8+ T cell responses restricted by major histocompatibility complex-E. Science, 2016; 351(6274): 714-720.

10. Jiang $Y$, Liu $T$, Effect of operating room care combined with home care for the postoperative rehabilitation and prognosis of gastric cancer patients with low PTEN gene expression. Oncol Lett., 2017; 14(2): 2119-2124.

11. Kikuchi J, Hashizume M, Kaneko Y, Yoshimoto K, Nishina N, Takeuchi T, Peripheral blood CD4 + $\mathrm{CD} 25+\mathrm{CD} 127$ low regulatory T cells are significantly increased by tocilizumab treatment in patients with rheumatoid arthritis: increase in regulatory $\mathrm{T}$ cells correlates with clinical response. Arthritis Res Ther., 2015; 17(1): 1-10.

12. Leylabadlo HE, Kafil HS, Yousefi M, Gastric cancer mortality in a high-incidence area (Ardabil Province, Northwest Iran): What risk factors are causative? Eur J Cancer Prev Offic J Eur Cancer Prev Organ., 2016; 25(6): 573-574.

13. Pawlowski P, Grubczak K, Kostecki J, IlendoPoskrobko E, Moniuszko M, Pawlowska M, Rejdak R, Reszec J, Mysliwiec J, Decreased frequencies of peripheral blood CD4+CD25+CD127-Foxp3+ in patients with Graves' disease and Graves' orbitopathy: Enhancing effect of insulin growth factor-1 on Treg cells. Horm Metab Res., 2017; 49(3): 185-191.

14. Rashid H, Alam K, Afroze D, Yousuf A, Banday M, Kawoosa F, Hypermethylation status of Ecadherin gene in gastric cancer patients in a high incidence area. Asian Pac J Cancer P., 2016; 17(6): 2757-2760.

15. Roy BL, Pereira B, Bouteloup C, Costes F, Richard R, Selvy M, Pétorin C, Gagnière J, Futier E, Slim K, Meunier B, Mabrut JY, Mariette C, Pezet D, 
Effect of prehabilitation in gastro-oesophageal adenocarcinoma: study protocol of a multicentric, randomised, control trial-the PREHAB study. $B M J$ Open, 2016; 6(12): 1-7.

16. Shao YB, Sun XF, He YN, Liu CJ, Liu H, Elevated levels of serum tumor markers CEA and CA15-3 are prognostic parameters for different molecular subtypes of breast cancer. Plos One, 2015; 10(7): $1-11$.

17. Stanculescu D, Margaritescu C, Stepan A, Mitrut $\mathrm{AO}, \mathrm{E}$-cadherin in gastric carcinomas related to histological prognostic parameters. Rom J Morphol Embryol., 2011; 52(3): 1107-1112.

18. Tongo I, Ogbeide O, Ezemonye L, Human health risk assessment of polycyclic aromatic hydrocarbons (PAHs) in smoked fish species from markets in Southern Nigeria Isioma. Toxicology Reports, 2017; 4: 55-61.

19. Tsiaoussis J, Vassilopoulou L, Nikolouzakis T, Rakitskii VN, Vakonaki E, Fragkiadaki P, Stivaktakis P, Tsatsakis AM, Biomolecular profile of colorectal cancer - the role of telomerase as a potent biomarker. Farmacia, 2017; 65(5): 643-659.

20. Wilhelm F, Böger C, Krüger S, Behrens HM, Röcken $\mathrm{C}$, Troy is expressed in human stomach mucosa and a novel putative prognostic marker of intestinal type gastric cancer. Oncotarget, 2017; 8(31): 50557-50569.

21. Yuan YQ, Pu XM, Xiao JK, Cai XA, A comparison study on the clinical effects of foscarnet sodium injection and interferon on human immunodeficiency virus-infected patients complicated with herpes zoster. Pak J Med Sci., 2015; 31(2): 309-313. 